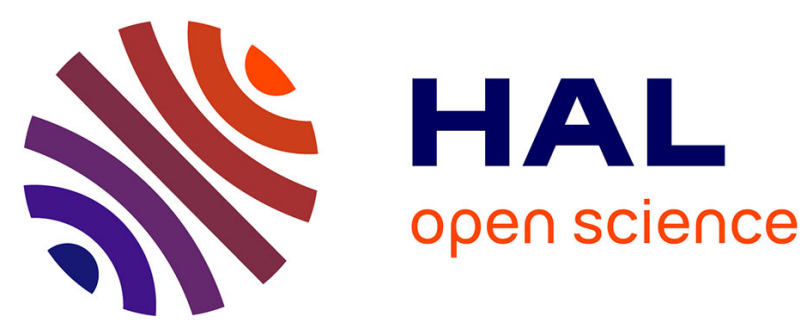

\title{
Immediate single-tooth implants in the anterior maxilla: 3-year results of a case series on hard and soft tissue response and aesthetics.
}

Jan Cosyn, Aryan Eghbali, Hugo de Bruyn, Kristiaan Collys, Roberto Cleymaet, Tim de Rouck

\section{To cite this version:}

Jan Cosyn, Aryan Eghbali, Hugo de Bruyn, Kristiaan Collys, Roberto Cleymaet, et al.. Immediate single-tooth implants in the anterior maxilla: 3-year results of a case series on hard and soft tissue response and aesthetics.. Journal of Clinical Periodontology, 2011, 38 (8), pp.746. 10.1111/j.1600051X.2011.01748.x . hal-00659530

\section{HAL Id: hal-00659530 https://hal.science/hal-00659530}

Submitted on 13 Jan 2012

HAL is a multi-disciplinary open access archive for the deposit and dissemination of scientific research documents, whether they are published or not. The documents may come from teaching and research institutions in France or abroad, or from public or private research centers.
L'archive ouverte pluridisciplinaire HAL, est destinée au dépôt et à la diffusion de documents scientifiques de niveau recherche, publiés ou non, émanant des établissements d'enseignement et de recherche français ou étrangers, des laboratoires publics ou privés. 


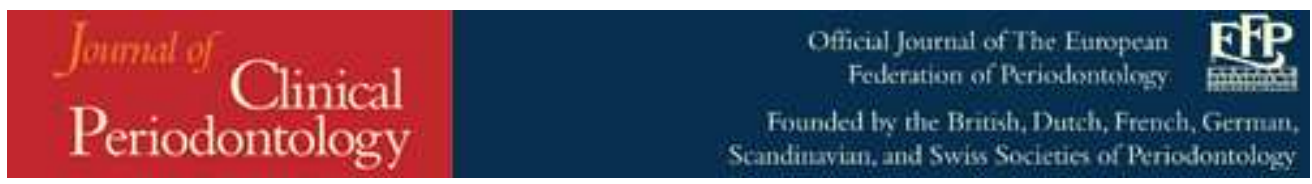

\section{Immediate single-tooth implants in the anterior maxilla: 3- year results of a case series on hard and soft tissue response and aesthetics.}

\begin{tabular}{|r|l|}
\hline Journal: & Journal of Clinical Periodontology \\
\hline Manuscript ID: & CPE-12-10-2991.R1 \\
\hline Manuscript Type: & Original Article Implant Dentistry \\
\hline Date Submitted by the & 14-Mar-2011 \\
\hline Complete List of Authors: & $\begin{array}{l}\text { Cosyn, Jan; Ghent University, School of Dental Medicine, } \\
\text { Department of Periodontology and Oral Implantology } \\
\text { Eghbali, Aryan; Ghent University, School of Dental Medicine, } \\
\text { Department of Periodontology and Oral Implantology } \\
\text { De Bruyn, Hugo; University of Ghent, Department of Periodontology } \\
\text { Collys, Kristiaan; Free University of Brussels (VUB), Department of } \\
\text { Restaurative Dentistry } \\
\text { Cleymaet, Roberto; Free University of Brussels (VUB), Department } \\
\text { of Restaurative Dentistry } \\
\text { De Rouck, Tim; Free University of Brussels (VUB), Department of } \\
\text { Restaurative Dentistry; University of Ghent, Department of } \\
\text { Prosthodontics }\end{array}$ \\
\hline Main Methodology: & \begin{tabular}{l} 
Implantology \\
\hline Topical Trial
\end{tabular} \\
\hline \hline & \begin{tabular}{l} 
Clintal implant, single tooth, immediate, maxilla, pink esthetic score \\
\hline Thords:
\end{tabular} \\
\hline \hline
\end{tabular}

\section{SCHOLARONE" \\ Manuscripts}


Submission to Journal of Clinical Periodontology (CPE-12-10-2991.R1)

\title{
$\underline{\text { TITLE }}$
}

Immediate single-tooth implants in the anterior maxilla: 3-year results of a case series on hard and soft tissue response and aesthetics.

\author{
RUNNING TITLE \\ Immediate single-tooth implants
}

\section{$\underline{\text { KEY WORDS }}$}

Dental implant, single tooth, immediate, maxilla, pink esthetic score, white esthetic score

\section{$\underline{\text { AUTHORS }}$}

Cosyn, J., Eghbali, A., De Bruyn, H., Collys, K., Cleymaet, R., De Rouck, T.

\section{AFFILIATIONS AND INSTITUTIONS}

Jan Cosyn ${ }^{1,2}$, Aryan Eghbali ${ }^{1,2}$, Hugo De Bruyn ${ }^{1}$, Kristiaan Collys ${ }^{2}$, Roberto Cleymaet ${ }^{2}$, Tim De Rouck ${ }^{2,3}$

${ }^{1}$ University of Ghent, Faculty of Medicine and Health Sciences, Dental School, Department of Periodontology and Oral Implantology, De Pintelaan 185, B-9000 Ghent, Belgium

${ }^{2}$ Free University of Brussels (VUB), Dental Medicine, Laarbeeklaan 103, B-1090 Brussels, Belgium

${ }^{3}$ University of Ghent, Faculty of Medicine and Health Sciences, Dental School, Department of Prosthodontics, De Pintelaan 185, B-9000 Ghent, Belgium

\section{CONTACT ADDRESS CORRESPONDING AUTHOR}

Dr. Jan Cosyn

University of Ghent, Faculty of Medicine and Health Sciences, Dental School, Department of Periodontology and Oral Implantology, De Pintelaan 185, B-9000 Ghent, Belgium

E-mail: jan.cosyn@ugent.be 


\section{CONFLICT OF INTERESTS AND SOURCE OF FUNDING}

The authors declare that they have no conflict of interests. The study was supported by the dental department of the Free University of Brussels (VUB). The authors wish to express their gratitude to Nobel Biocare Belgium for their support in providing dental implants.

\section{$\underline{\text { ABSTRACT }}$}

Purpose: The objective of this prospective study was to assess the overall outcome of immediate single implant treatment in the anterior maxilla after a 3-year observation period.

Material and methods: Thirty consecutively treated patients with a thick gingival biotype, ideal gingival level/contour and intact socket walls at the time of tooth extraction were treated for single-tooth replacement in the aesthetic zone by two experienced clinicians. Treatment included minimal mucoperiosteal flap elevation, immediate implant placement (Nobelreplace TiUnite ${ }^{\circledR}$, Nobel Biocare, Göteborg, Sweden), insertion of a grafting material between the implant and the socket wall and connection of a screw-retained provisional restoration. The latter was replaced by a cemented crown 6 months thereafter. Patients were clinically and radiographically re-examined after 3 years to assess implant survival, complications and hard and soft tissue conditions. The aesthetic outcome was objectively rated using the Pink Esthetic Score (PES) and White Esthetic Scrore (WES) by a blinded clinician who had not been involved in the treatment.

Results: Twenty-five patients could be re-evaluated after 3 years. One early implant failure had occurred resulting in an implant survival rate of $96 \%$. Radiographic examination yielded on average $1.13 \mathrm{~mm}$ mesial, respectively $0.86 \mathrm{~mm}$ distal bone loss. The clinical conditions showed fairly low peri-implant plaque (18\%) and bleeding (24\%) and mean probing depth was $3.17 \mathrm{~mm}$. Mean mesial/distal papilla shrinkage and midfacial soft tissue recession in reference to the pre-operative status accounted for $0.05 \mathrm{~mm}, 0.08 \mathrm{~mm}$ and $0.34 \mathrm{~mm}$, respectively. Between the 1- and 3-year reassessment mesial papillae showed significant re-growth $(0.36 \mathrm{~mm} ; p$ $=0.015)$. Advanced midfacial recession $(>1 \mathrm{~mm})$ was found in $2 / 25(8 \%)$ cases. Five $(21 \%)$ cases were aesthetic failures (PES $<8$ and/or WES $<6$ ) and 5/24 (21\%) showed an (almost) perfect outcome (PES $\geq 12$ and WES $\geq 9)$. The remainder ( $14 / 24$ or $58 \%)$ demonstrated acceptable aesthetics.

Conclusions: The proposed strategy seems a valuable and predictable treatment option for well-selected patients in the mid-long term as shown by almost full papillary re-growth and a low risk for advanced midfacial recession. 
1

2

4

\section{CLINICAL RELEVANCE}

Scientific rationale: Ample studies have been published on immediate single implant treatment. However, no data have been reported on hard and soft tissue response and aesthetic outcome after a 3-year observation period. Principal findings: One early failure occurred and mean bone loss was $1 \mathrm{~mm}$. Papillae showed almost full regrowth and only $2 / 25(8 \%)$ cases demonstrated advanced midfacial recession (>1 mm). Nineteen $(79 \%)$ cases showed acceptable to excellent aesthetics.

Practical implications: This strategy seems a valuable and predictable option for well-selected patients in the mid-long term. Main advantages include time gain, immediate aesthetics and comfort. 


\section{Introduction}

Single implant treatment in the anterior maxilla is considered highly predictable and successful, at least in terms of implant survival and hard tissue remodelling following conventional implant surgery (Creugers et al. 2000, Berglundh et al. 2002, den Hartog et al. 2008, Jung et al. 2008). Hitherto, aesthetic aspects of therapy have only been sporadically reported even though these are more and more becoming the key for success in daily practice. The latter may be a reflection of an evolving society with more demanding patients expecting a restoration to be an exact copy of the original tooth and finalized within the shortest possible time span. Consequently, implant protocols have been reassessed ultimately resulting in immediate implant placement and restoration. Albeit this strategy offers obvious advantages such as time gain, immediate aesthetics and comfort, immediate implantation may not avert post-extraction remodelling (Botticelli et al. 2004, Araújo et al. 2005). As such, immediate single implant treatment may be a risky procedure in terms of soft tissue stability especially when patients are improperly selected and surgery is performed by inexperienced clinicians (De Rouck et al. 2008b). To reduce the risk for advanced midfacial soft tissue recession a number of prerequisites have been described (De Rouck et al. 2008b). At least in the short term, immediate implant placement has shown to be predictable under these conditions (Kan et al. 2003a, De Rouck et al. 2008a). The purpose of the present study was to document the overall outcome of immediate single implant treatment in the anterior maxilla in the mid-long term focusing on soft tissue dynamics and aesthetic aspects. The research hypothesis was that this treatment concept would demonstrate a low risk for advanced midfacial recession after 3 years of function.

\section{Material and Methods}

\section{Patient selection}

This prospective study was based on data from patients who had been treated for immediate single-tooth implants at the Dental Clinic of the Free University in Brussels (VUB). The 1-year results were previously published by De Rouck and co-workers (2008a). This paper addressed the outcome of the same study sample after 3 years of function focusing on soft tissue dynamics between the 1- and 3-year reassessment and aesthetic aspects. Patients were selected during a screening visit on the basis of inclusion and exclusion criteria.

Inclusion criteria were as follows:

1. At least 18 years old.

2. Good oral hygiene defined as full-mouth plaque score $\leq 25 \%$ (O’Leary et al. 1972).

3. Presence of a single failing tooth in the anterior maxilla (15-25) with both neighbouring teeth present. 
4. Ideal soft tissue level/contour at the facial aspect of the failing tooth in perfect harmony with the surrounding teeth.

5. Thick gingival biotype as determined by De Rouck et al. (2009b).

6. Adequate bone height apical to the alveolus of the failing tooth $(\geq 5 \mathrm{~mm})$ to ensure primary implant stability of at least $35 \mathrm{Ncm}$.

Exclusion criteria were as follows:

1. Systemic diseases.

2. Smoking.

3. Bruxism, lack of posterior occlusion.

4. Non-treated periodontal diseases.

5. Presence of active infection (pus, fistula) around the failing tooth.

6. Loss of the buccal bone crest after extraction of the failing tooth.

The study was conducted in accordance with the Helsinki declaration of 1975 as revised in 2000.

\section{Surgical procedure}

Following screening, comprehensive clinical and radiographic examination was performed by two experienced clinicians (JC/TDR). All patients consented to the planned treatment strategy. The surgical procedure can be found in detail in a previous paper (De Rouck et al. 2008a). Briefly, patients were advised to start antibiotic (Amoxicillin $500 \mathrm{mg}$ ) and analgesic therapy (Ibuprofen $600 \mathrm{mg}$ ) one hour pre-operatively and oral disinfection $\left(\right.$ Corsodyl $^{\circledR}$, GlaxoSmithKline, Genval, Belgium) was done just prior to surgery. Teeth scheduled for immediate replacement were removed as atraumatically as possible using periotomes after minimal mucoperiosteal flap elevation including the papillae of both adjacent teeth. Immediate implant placement (Nobelreplace tapered TiUnite $^{\circledR}$, Nobel Biocare, Göteborg, Sweden) was performed if the buccal bone crest was intact. Special attention was paid to a correct selection and three-dimensional positioning of the implant as described by Buser et al. (2004). Following confirmation of the primary stability using a Torque Controller (Nobel Biocare, Göteborg, Sweden), implant impression was made. Deproteinized bovine bone particles (Bio-Oss ${ }^{\circledR} 0.25-1 \mathrm{~mm}$, Geistlich Biomaterials, Wolhusen, Switzerland) soaked in blood were inserted to fill the void between the implant and the alveolus. Finally, an appropriate healing abutment was installed and the wound was closed by means of single sutures (Vicryl $^{\circledR} 5 / 0$, Johnson \& Johnson, St-Stevens-Woluwe, Belgium). All surgical procedures were performed by one and the same experienced implant surgeon (JC). 


\section{Restorative procedures}

For details on the restorative and technical procedures, we wish to refer to a previous paper (De Rouck et al. 2008a). Briefly, an individualized screw-retained provisional crown was fabricated in the dental laboratory using the implant impression taken at the time of surgery. An engaging titanium temporary abutment (Nobel Biocare, Göteborg, Sweden) served as a carrier for an appropriate hollowed denture tooth. Approximately $3 \mathrm{~h}$ following implant installation the temporary crown was placed and tightened by one and the same experienced prosthodontist (TDR) at $15 \mathrm{Ncm}$ onto the fixture. The provisional restoration was adjusted to clear centric and eccentric contacts in order to avoid full functional load.

After 6 months, the provisional restoration was replaced by a permanent cemented restoration. A standard aesthetic titanium abutment (Esthetic Abutment, Nobel Biocare, Göteborg, Sweden) was used to connect the permanent metal-ceramic restoration. Cementation was performed using temporary cement (Temp-Bond $\mathrm{NE}^{\circledR}$, Kerr, Scafati, Italy). All prosthetic procedures were conducted by one and the same experienced prosthodontist (TDR) and all permanent restorations were fabricated in one and the same dental laboratory (Dental Art, Zottegem, Belgium).

Implant survival and complications

As performed during the first year of function, patients were evaluated for implant survival and complications after 3 years. A distinction was made between biologic and technical complications.

\section{Hard tissue parameters}

As performed during the first year of function, a peri-apical radiograph using the long-cone paralleling technique was taken after 3 years. Each X-ray holder (XCP Bite Block ${ }^{\circledR}$, Dentsply Rinn, Elgin, IL, USA) had been individualized with an occlusal jig (Futar D Fast ${ }^{\circledR}$, Kettenbach Dental, Eschenburg, Germany) in order to standardize the procedure. Changes in marginal bone levels at the mesial and distal aspect of the implant were determined following digitalization (SprintScan 35 Plus $^{\circledR}$, Polaroid, Cambridge, MA, USA) and by using the appropriate software (Vixwin 2000 v1.11 ${ }^{\circledR}$, Dentsply Gendex, Lake Zurich, Switserland). Details can be found in a preceding paper (De Rouck et al. 2008a).

\section{Soft tissue parameters}

As performed during the first year of function, the clinical condition of the implant restoration was evaluated after 3 years by means of the following parameters: 


\section{Aesthetic outcome}

All aesthetic evaluations relating to the soft tissues and implant crowns were performed by one clinician (AE) who had not been involved in any treatment. This clinician was calibrated prior to the study on the basis of 20 single implant cases in the anterior maxilla. Per case a frontal and occlusal colour slide was available and each case was scored twice with an interval of one week. The 20 single implant cases were also scored by another clinician (JC). The results on the intra- and inter-examiner reliability can be found in a recent paper (Cosyn et al. 2010).

The Pink Esthetic Score (PES) by Fürhauser et al. (2005) was used to evaluate the aesthetic outcome of the periimplant soft tissues. This index includes 7 variables: mesial papilla, distal papilla, midfacial level, midfacial contour, alveolar process deficiency, soft tissue colour and soft tissue texture. Each parameter is assessed with a 0-1-2 score with 2 being the best and 0 being the worst score. Thus, a maximum score of 14 can be reached. 


\section{Statistical analysis}

Data analysis was performed using the patient as the experimental unit. For all parameters mean values were calculated, if applicable. Descriptive statistics also included frequency distributions for papillae and midfacial mucosa level. The changes between the 1- and 3-year reassessment were examined using the Wilcoxon signed ranks test. The level of significance was set at 0.05 .

\section{Results}

From the 32 patients who had been scheduled from May 2005 to June 2006, 30 (14 men, 16 women; mean age of 54 with a range from $24-76$ ) were treated for single-tooth replacement in the aesthetic zone by means of an immediate implant (Nobelreplace tapered TiUnite ${ }^{\circledR}$, Nobel Biocare, Göteborg, Sweden). Two patients had to be excluded during surgery as loss of the buccal bone crest had occurred after tooth extraction. For details on the reasons for tooth loss, implant locations and dimensions, we wish to refer to an earlier paper (De Rouck et al. 2008a). During the 3-year observation period, 1 and 3 patients were lost to follow-up after 3 and 12 months, respectively. One of them moved and 1 could not be contacted even after several attempts. The other 2 patients agreed to come in for evaluation but did not show up in the end. 


\section{(HERE APPROXIMATELY TABLE 1 PLEASE)}

\section{Soft tissue parameters}

In table 2 the clinical conditions of the implant restorations are shown. Throughout the study period, mean plaque levels remained low $(<20 \%)$ indicating good oral hygiene. Between 1 and 3 years, a significant reduction in probing depth from $3.46 \mathrm{~mm}$ to $3.17 \mathrm{~mm}(p=0.015)$ occurred coinciding with a significant bleeding on probing drop from $41 \%$ to $24 \%(p=0.002)$.

\section{(HERE APPROXIMATELY TABLE 2 PLEASE)}

Table 3 depicts the dimensional changes of the soft tissue outline around the implant restorations in relation to the status prior to tooth extraction. Mesial papillae showed a significant re-growth between 1 and 3 years $(p=$ 0.015) pointing to a mean loss of only $0.05 \mathrm{~mm}$ from the pre-operative status at study termination. A similar trend was found for distal papillae $(p=0.117$ ) resulting in a final mean loss of $0.08 \mathrm{~mm}$. At 3 years follow-up severe mesial papilla loss $(>1 \mathrm{~mm})$ was found in 1/25 (4\%) and severe distal papilla loss (>1 mm) in 4/25 (16 $\%$ ) cases. In 13/25 (52\%) patients mesial papillae regained at least their original height. In 14/25 (56\%) patients distal papillae regained at least their original height. 
The midfacial mucosa level did not alter significantly between the 1- and 3-year reassessment $(p=0.135)$. At study termination a mean recession from the pre-operative status of $0.34 \mathrm{~mm}$ was found (table 3 ). At 3 years follow-up advanced midfacial recession $(>1 \mathrm{~mm})$ was found in 2/25 (8\%) cases. In 10/25 (40\%) patients the midfacial mucosa regained at least its original level.

A case is shown in figure 1 illustrating papillary re-growth and stability of the midfacial mucosa level between the 1- and 3-year reassessment.

\section{(HERE APPROXIMATELY TABLE 3, FIGURE 1 PLEASE)}

\section{Aesthetic outcome}

Table 4 shows the results of all 7 criteria of the PES. Midfacial level and soft tissue colour were most satisfying showing a perfect match with the corresponding tooth in 17/25 (70 \%) cases. Unfavourable results were most prevalent for the alveolar process showing severe deficiency in 5/25 (20\%) cases.

The mean PES was 10.48 (SD 2.47; range 5 - 14). Figure 2 shows the cumulative percent of the PES. Dotted lines indicate the upper limit for an unacceptable result $(\mathrm{PES}=7)$ and a favourable, yet imperfect result $(\mathrm{PES}=$ 11). Four out of $25(16 \%)$ cases showed an unfavourable outcome and 9/25 (36\%) an (almost) perfect result.

(HERE APPROXIMATELY TABLE 4 \& FIGURE 2 PLEASE)

Table 4 shows the results of all 5 criteria of the WES. Since 1 patient refused to replace the provisional restoration, the results on the WES were based on 24 cases.

Tooth texture was most satisfying indicating an ideal result in 21/24 (88 \%) cases. Unfavourable results were most prevalent for tooth colour with a severe mismatch in 5/24 (21\%) and a perfect result in only 9/24 (38\%) cases.

The mean WES was 8.17 (SD 1.52; range 5 - 10). Figure 3 shows the cumulative percent of the WES. Dotted lines indicate the upper limit for an unacceptable result $(\mathrm{PES}=5)$ and a favourable, yet imperfect result $(\mathrm{PES}=$ 8). Two out of 24 (8\%) cases showed an unfavourable outcome and 12/24 (50\%) an (almost) perfect result.

(HERE APPROXIMATELY FIGURE 3 PLEASE) 


\section{Discussion}

In the present study $96 \%$ of the implants survived and mean bone loss was $1 \mathrm{~mm}$ after 3 years of function. These data correspond well with the existing knowledge on survival and bone remodelling of conventionally installed single TiUnite ${ }^{\circledR}$ (Nobel Biocare, Göteborg, Sweden) implants after a comparable observation period (Turkyilmaz et al. 2007, De Bruyn et al. 2009, Eghbali et al. 2010). Hence, the timing of implant placement relative to tooth extraction does not seem to be decisive for implant survival or bone remodelling, which has also been demonstrated by at least 4 controlled clinical studies using various implant systems (Lindeboom et al. 2006, Palatella et al. 2008, Block et al. 2009, Van Kesteren et al. 2010).

As described in a systematic review on single implants in the anterior maxilla (den Hartog et al. 2008), few reports included data on clinical parameters. In our study plaque levels were fairly low and comparable between the 1- and 3-year reassessment. In contrast, probing depth and bleeding on probing significantly reduced within this time frame. This trend had already started in the first year (De Rouck et al. 2008a). Similar observations have been described in other short- (Proussaefs et al. 2002) and long-term studies (Apse et al. 1991).

Even though a number of reports are available on immediate single implant treatment, few prospective studies have been published with data on soft tissue dynamics (Kan et al. 2003a, De Rouck et al. 2008a, Palatella et al. 2008, Block et al. 2009, Van Kesteren et al. 2010, Raes et al. 2011). However, these papers all described shortterm results with observations up to 2 years. The results of the present 3-year study showed that papillae had not fully remodelled after 1 year of function. Significant papillary re-growth was observed especially at the mesial aspect and at the 3-year reassessment papillae had basically regained their original height. These findings indicate that the presence of papillae may not be the key issue following immediate single implant treatment providing these were intact at the time of tooth loss. Similar observations have been described following conventional implant surgery (Jemt 1997, Choquet et al. 2001, Kan et al. 2003b, Henriksson \& Jemt 2004, 
Cardaropoli et al. 2006). In these studies the bone peak at the adjacent tooth was considered the pivotal factor in maintaining papilla height between a single implant and tooth.

An issue that gained at lot of attention in recent studies relates to the midfacial mucosa level following immediate single implant treatment (Lindeboom et al. 2006, Chen et al. 2007, Juodzbalys \& Wang 2007, Kan et al. 2007, De Rouck et al. 2008a, Evans \& Chen 2008, Palatella et al. 2008, Block et al. 2009, Chen et al. 2009, Redemagni et al. 2009, Van Kesteren et al. 2010, Raes et al. 2011). According to a review article immediate implants show an increased risk for advanced midfacial recession (> $1 \mathrm{~mm}$ ) (Chen \& Buser 2009). However, only $2 / 25(8 \%)$ of our cases demonstrated more than $1 \mathrm{~mm}$ recession and mean loss was only $0.34 \mathrm{~mm}$ after 3 years without deterioration between the 1- and 3-year reassessment. In addition, of all the criteria of the PES midfacial level was most satisfying. On the basis of these observations, the risk for advanced midfacial recession was clearly low in our patients, hereby confirming the aforementioned research hypothesis. Interestingly, our findings contrast the conclusion of a review article by Chen \& Buser (2009), yet seem to be in agreement with 3 controlled clinical studies describing a low risk for advanced midfacial recession following immediate single implant treatment (Palatella et al. 2008, Block et al. 2009, Van Kesteren et al. 2010). This contradiction is interesting and may be explained by disparities in study design (prospective versus retrospective), recording procedure (using a stent or standardized digital slides with fixed reference points or not), case selection (thinscalloped biotype cases excluded or not; buccal bone crest intact or not), surgical aspects (surgeon's experience; implant type; orofacial implant positioning; hard and/or soft tissue grafting or not) and restorative aspects (immediate provisionalisation or not). Given the complexity of this aspect of treatment outcome, a thorough systematic review would be valuable specifically comparing the risk for advanced midfacial recession between immediate and conventional single implant treatment.

Aesthetic aspects relating to the soft tissues and implant crown are more and more becoming the key for success. Although ample reports have been published on immediate implantation and restoration, few have documented the aesthetic outcome using objective criteria (Juodzbalys \& Wang 2007, Chen et al. 2009, Raes et al. 2011). Since these papers all described short-term results with observations up to 1 year we believe this 3-year paper may add relevant information. When scrutinizing the results on the PES, $16 \%$ of all cases showed an unfavourable outcome (PES $\leq 7$ ), which is slightly higher when compared to earlier findings in the short term (0 \%-11\%) (Juodzbalys \& Wang 2007, Chen et al. 2009, Raes et al. 2011). On the other hand, $36 \%$ of our cases showed an (almost) perfect outcome (PES $\geq 12$ ), which resembles quite well with available data (26\% - $39 \%$ ) (Juodzbalys \& Wang 2007, Chen et al. 2009, Raes et al. 2011). 
To our knowledge only 4 case series have been published documenting the aesthetic characteristics of single implants crowns (Belser et al. 2009, Buser et al. 2009, Cosyn et al. 2010, Raes et al. 2011). In the present study 8 $\%$ of the cases could be considered failures in this respect (WES $\leq 5$ ), which falls within the range described in the literature (0\% - $21 \%)$ (Belser et al. 2009, Buser et al. 2009, Cosyn et al. 2010, Raes et al. 2011). In addition, $50 \%$ of our cases showed an (almost) perfect result which is in agreement with others (Buser et al. 2009, Cosyn et al. 2010, Raes et al. 2011), yet in contrast with Belser et al. (2009) showing perfection in only $18 \%$ of the cases. In this regard it must be emphasized that patients had been sent back to the referring dentist for restorative treatment.

Of particular importance is the overall aesthetic outcome combining the results of the PES and WES. As such, $21 \%$ showed perfection (PES $\geq 12$ and WES $\geq 9$ ) which is quite modest, yet in agreement with the current knowledge on single implant treatment (7\% - $35 \%$ ) (Belser et al. 2009, Buser et al. 2009, Cosyn et al. 2010, Raes et al. 2011). Similarly, $21 \%$ of our cases could be considered aesthetic failures (PES $<8$ and/or WES $<6$ ) which also falls within the range of what has been published (5\%-34\%) (Meijndert et al. 2007, Belser et al. 2009, Buser et al. 2009, Cosyn et al. 2010, Raes et al. 2011). Clearly, optimal aesthetics seem difficult to achieve and failures are quite prevalent in spite of the fact that patients had been selected on the basis of stringent criteria and treated by experienced clinicians. It seems wise to warn patients for this relatively high risk.

In conclusion, the results of this 3 -year prospective study indicate that immediate single implant treatment may be considered a valuable and predictable option in terms of implant survival and hard and soft tissue remodelling. We observed in a 3-year time span nearly full papillary re-growth and a low risk for advanced midfacial recession with 19/24 (79 \%) cases showing acceptable to excellent aesthetics. In this context, we wish to emphasize the favourable starting point in all cases excluding high-risk patients with a thin-scalloped gingival biotype and/or buccal bone defect. Besides careful case selection, appropriate surgical and restorative procedures and clinical experience are also considered of pivotal importance. More prospective studies monitoring soft tissue dynamics over longer time periods are needed. Since it is currently unclear to what extent treatment modalities influence aesthetics, comparative studies specifically focusing on this aspect of treatment outcome would be valuable.

\section{References}


Apse, P., Zarb, G.A., Schmitt, A., Lewis, D.W. (1991) The longitudinal effectiveness of osseointegrated dental implants. The Toronto Study: peri-implant mucosal response. The International Journal of Periodontics and Restorative Dentistry 11, 94-111.

Araújo, M.G., Sukekava, F., Wennström, J.L., Lindhe, J. (2005) Ridge alterations following implant placement in fresh extraction sockets: an experimental study in the dog. Journal of Clinical Periodontology 32, 645-652.

Belser, U.C., Grütter, L., Vailati, F., Bornstein, M.M., Weber, H.P., Buser, D. (2009) Outcome evaluation of early placed maxillary anterior single-tooth implants using objective esthetic criteria: a cross-sectional, retrospective study in 45 patients with a 2- to 4 -year follow-up using pink and white esthetic scores. Journal of Periodontology 80, 140-151.

Berglundh, T., Persson, L., Klinge, B. (2002) A systematic review of the incidence of biological and technical complications in implant dentistry reported in prospective longitudinal studies of at least 5 years. Journal of Clinical Periodontology 29, 197-212.

Block, M.S., Mercante, D.E., Lirette, D., Mohamed, W., Ryser, M., Castellon, P. (2009) Prospective evaluation of immediate and delayed provisional single tooth restorations. International Journal of Oral and Maxillofacial Surgery 67, 89-107.

Botticelli, D., Berglundh, T., Lindhe, J. (2004) Hard-tissue alterations following immediate implant placement in extraction sites. Journal of Clinical Periodontology 31, 820-828. 
Buser, D., Halbritter, S., Hart, C., et al. (2009) Early implant placement with simultaneous guided bone regeneration following single-tooth extraction in the esthetic zone: 12-month results of a prospective study with 20 consecutive patients. Journal of Periodontology 80, 152-162.

Buser, D., Martin, W., Belser, U.C. (2004) Optimizing esthetics for implant restorations in the anterior maxilla: anatomic and surgical considerations. International Journal of Oral and Maxillofacial Implants 19, 43-61.

Cardaropoli, G., Lekholm, U., Wennstrom, J.L. (2006) Tissue alternation at implant-supported single-tooth replacements: a 1-year prospective clinical study. Clinical Oral Implants Research 17, 165-171.

Chen, S.T., Buser D. (2009) Clinical and esthetic outcomes of implants placed in postextraction sites. International Journal of Oral and Maxillofacial Implants 24, 186-217.

Chen, S.T., Darby, I.B., Reynolds, E.C. (2007) A prospective clinical study of non-submerged immediate implants: clinical outcomes and esthetic results. Clinical Oral Implants Research 18, 552-562.

Chen, S.T., Darby, I.B., Reynolds, E.C., Clement, J.G. (2009) Immediate implant placement postextraction without flap elevation. Journal of Periodontology 80, 163-172.

Choquet, V., Hermans, M., Adriaenssens, P., Daelemans, P., Tarnow, D.P., Malevez, C. (2001) Clinical and radiographic evaluation of the papilla level adjacent to single-tooth dental implants. A retrospective study in the maxillary anterior region. Journal of Periodontology 72, 1364-1371. 
Cosyn, J., Eghbali, A., De Bruyn, H., Dierens, M., De Rouck, T. (2010) Single implant treatment in healing versus healed sites of the anterior maxilla: an aesthetic evaluation. Clinical Implant Dentistry and Related Research In Press.

Creugers, N.H., Kreulen, C.M., Snoek, P.A., De Kanter, R.J. (2000) A systematic review of single-tooth restorations supported by implants. Journal of Dentistry 28, 209-217.

De Bruyn, H., Atashkadeh, M., Cosyn, J., Van De Velde, T. (2009) Clinical outcome and bone preservation of single TiUnite implants installed with flapless or flap surgery. Clinical Implant Dentistry and Related Research In Press.

den Hartog, L., Huddleston Slater, J.J.R., Vissink, A., Meijer, H.J.A., Raghoebar, G.M. (2008) Treatment outcome of immediate, early and conventional single-tooth implants in the aesthetic zone: a systematic review to survival, bone level, soft-tissue, aesthetics and patient satisfaction. Journal of Clinical Periodontology 35, 10731086.

De Rouck, T., Collys, K., Cosyn, J. (2008a) Immediate single-tooth implants in the anterior maxilla: a 1-year case cohort study on hard and soft tissue response. Journal of Clinical Periodontology 35, 649-657.

De Rouck, T., Collys, K., Cosyn, J. (2008b) Single-tooth replacement in the anterior maxilla by means of immediate implantation and provisionalization: a review. International Journal of Oral and Maxillofacial Implants 23, 897-904. 
De Rouck, T., Collys, K., Wyn, I., Cosyn, J. (2009a) Instant provisionalization of immediate single-tooth implants is essential to optimize esthetic treatment outcome. Clinical Oral Implants Research 20, 566-570.

De Rouck, T., Eghbali, A., Collys, K., De Bruyn, H., Cosyn, J. (2009b) The gingival biotype revisited: transparency of the periodontal proble through the gingival margin as a method to discriminate thin from thick gingiva. Journal of Clinical Periodontology 36, 428-433.

Eghbali, A., De Bruyn, H., De Rouck, T., Cleymaet, R., Wyn, I., Cosyn, J. (2010) Single implant treatment in healing versus healed sites of the anterior maxilla: a clinical and radiographic evaluation. Clinical Implant Dentistry and Related Research In Press.

Evans, C.D., Chen, S.T. (2008) Esthetic outcomes of immediate implant placements. Clinical Oral Implants Research 19, 73-80.

Fürhauser, R., Florescu, D., Benesch, T., Haas, R., Mailath, G., Watzek, G. (2005) Evaluation of soft tissue around single-tooth implant crowns: the pink esthetic score. Clinical Oral Implants Research 16, 639-644.

Henriksson, K., Jemt, T. (2004) Measurements of soft tissue volume in association with single-implant restorations: a 1-year comparative study after abutment connection surgery. Clinical Implant Dentistry and Related Research 6, 181-189. 
Jemt, T. (1997) Regeneration of gingival papillae after single-implant treatment. International Journal of Periodontics and Restorative Dentistry 17, 326-333.

Juodzbalys, G., Wang, H.L. (2007) Soft and hard tissue assessment of immediate implant placement: a case series. Clinical Oral Implants Research 18, 237-243.

Jung, R.E., Pjetursson, B.E., Glauser, R., Zembic, A., Zwahlen, M., Lang, N.P. (2008) A systematic review of the 5-year survival and complication rate of implant-supported single crowns. Clinical Oral Implants Research 19, $119-130$.

Kan, J.Y., Rungcharassaeng, K., Lozada, J. (2003a) Immediate placement and provisionalization of maxillary anterior single implants: 1-year prospective study. International Journal of Oral and Maxillofacial Implants 18, 31-39.

Kan, J.Y., Rungcharassaeng, K., Sclar, A., Lozada, J.L. (2007) Effects of the facial osseous defect morphology on gingival dynamics after immediate tooth replacement and guided bone regeneration: 1-year results. International Journal of Oral and Maxillofacial Surgery 65, 13-19.

Kan, J.Y., Rungcharassaeng, K., Umezu, K., Kois, J.C. (2003b) Dimensions of peri-implant mucosa: an evaluation of maxillary anterior single implants in humans. Journal of Periodontology 74, 557-562. 
Palattella, P., Torsello, F., Cordaro, L. (2008) Two-year prospective clinical comparison of immediate replacement vs. immediate restoration of single tooth in the aesthetic zone. Clinical Oral Implants Research 19, $1148-1153$.

Proussaefs, P., Kan, J., Lozada, J., Kleinman, A., Farnos, A. (2002) Effects of immediate loading with threaded hydroxyapatite-coated root-form implants on single premolar replacements: a preliminary report. International Journal of Oral and Maxillofacial Implants 17, 567-572.

Raes, F., Cosyn, J., Crommelinck, E., Coessens, P., De Bruyn, H. (2011) Immediate and conventional single implant treatment in the anterior maxilla: one-year results of a case series on hard and soft tissue remodelling and aesthetics. Journal of Clinical Periodontology 38, 385-394. 
Redegmagni, M., Cremonesi, S., Garlini, G., Maiorana, C. (2009) Soft tissue stability with immediate implants and concave abutments. European Journal of Esthetic Dentistry 4, 328-337.

Turkyilmaz, I., Avci, M., Kuran, S., Ozbek, E.N. (2007) A 4-year prospective clinical and radiological study of maxillary dental implants supporting single-tooth crowns using early and delayed loading protocols. Clinical Implant Dentistry and Related Research 9, 222-227.

van Kesteren, C.J., Schoolfield, J., West, J., Oates, T. (2010) A prospective randomized clinical study of changes in soft tissue position following immediate and delayed implant placement. International Journal of Oral and Maxillofacial Implants 25, 562-570. 


\section{TABLES}

Table 1. Marginal bone loss in relation to baseline (implant installation) at 1 and 3 years

\begin{tabular}{lccc}
\hline Location & 1 year $(\mathrm{n}=28)$ & 3 years $(\mathrm{n}=25)$ & $p$-value \\
\hline Mesial bone loss $(\mathrm{mm})$ & $0.98(0.50)[0.00 ; 2.10]$ & $1.13(0.43)[0.30 ; 2.10]$ & 0.038 \\
Distal bone loss $(\mathrm{mm})$ & $0.78(0.55)[0.10 ; 2.10]$ & $0.86(0.54)[0.30 ; 2.30]$ & 0.034 \\
\hline
\end{tabular}

$\mathrm{n}$ number of patients

Mean (SD) [range] 
Table 2. Clinical conditions at 1 and 3 years

\begin{tabular}{lccc}
\hline Location & 1 year $(\mathrm{n}=28)$ & 3 years $(\mathrm{n}=25)$ & $p$-value \\
\hline Plaque score $(\%)$ & $17(18)[0 ; 50]$ & $18(17)[0 ; 50]$ & 0.668 \\
Probing depth $(\mathrm{mm})$ & $3.46(0.69)[2.00 ; 4.70]$ & $3.17(0.63)[2.00 ; 4.30]$ & 0.015 \\
Bleeding on probing $(\%)$ & $41(16)[0 ; 75]$ & $24(19)[0 ; 50]$ & 0.002 \\
\hline
\end{tabular}

$\mathrm{n}$ number of patients

Mean (SD) [range] 
Table 3. Changes in soft tissue dimensions in relation to the pre-operative status at 1 and 3 years

\begin{tabular}{lccc}
\hline Location & 1 year $(\mathrm{n}=28)$ & 3 years $(\mathrm{n}=25)$ & $p$-value \\
\hline $\begin{array}{l}\text { Mesial papilla } \\
(\mathrm{mm})\end{array}$ & $-0.41(0.71)[-2.0 ; 0.5]$ & $-0.05(0.83)[-1.5 ; 1.5]$ & 0.015 \\
$\begin{array}{l}\text { Distal papilla } \\
(\mathrm{mm})\end{array}$ & $-0.31(0.83)[-2.0 ; 1.0]$ & $-0.08(1.24)[-2.5 ; 2.5]$ & 0.117 \\
$\begin{array}{l}\text { Midfacial mucosa level } \\
(\mathrm{mm})\end{array}$ & $-0.53(0.76)[-2.0 ; 0.5]$ & $-0.34(0.80)[-2.0 ; 1.0]$ & 0.135 \\
\hline $\begin{array}{l}\text { n number of patients } \\
\text { Mean (SD) [range]; negative value indicates recession in relation to the pre-operative status }\end{array}$
\end{tabular}


Table 4. Aesthetic outcome at 3 years

\begin{tabular}{llcc}
\hline Parameter & 0 & 1 & 2 \\
\hline Mesial papilla & 2 & 10 & 13 \\
Distal papilla & 4 & 8 & 13 \\
Midfacial level & 2 & 6 & 17 \\
Midfacial contour & 2 & 11 & 12 \\
Alveolar process deficiency & 5 & 4 & 16 \\
Soft tissue colour & 1 & 7 & 17 \\
Soft tissue texture & 1 & 8 & 16 \\
\hline Pink Esthetic Score $(\mathrm{n}=25)$ & & $10.48(2.47)[5-14]$ & 14 \\
Mean (SD) [range] & & 10 & 19 \\
\hline Tooth form & 0 & 5 & 21 \\
Tooth volume & 0 & 10 & 19 \\
Tooth colour & 5 & 3 & \\
Tooth texture & 0 & 4 & \\
Translucency & 1 & $8.17(1.52)[5-10]$ & \\
\hline White Esthetic Score $(\mathrm{n}=24)$ & & & \\
Mean (SD) [range] & & & \\
\hline
\end{tabular}




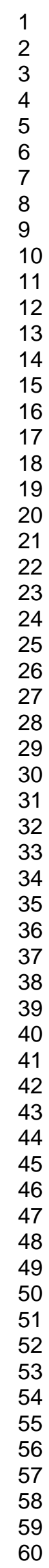

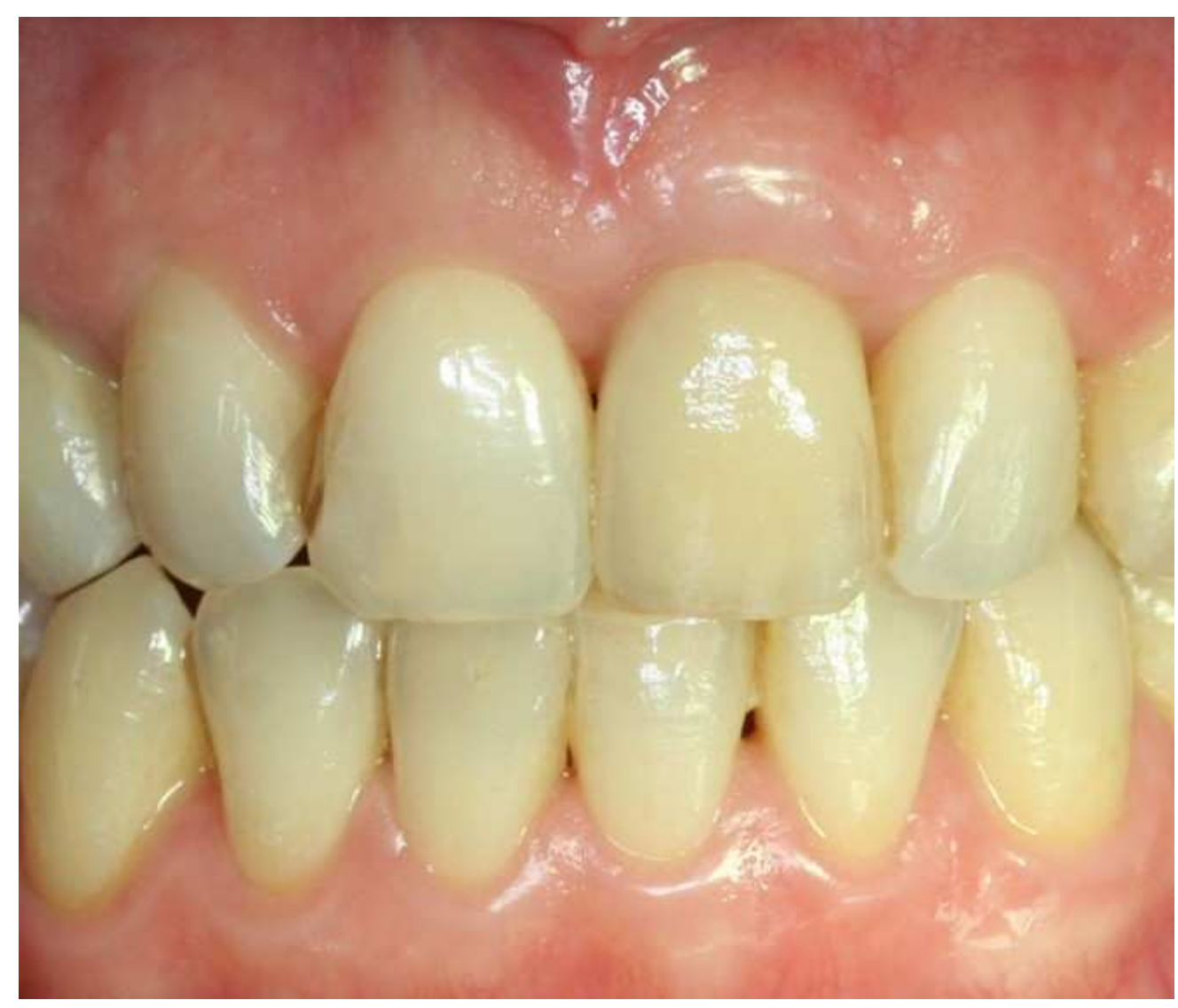

$234 \times 200 \mathrm{~mm}(72 \times 72$ DPI $)$ 


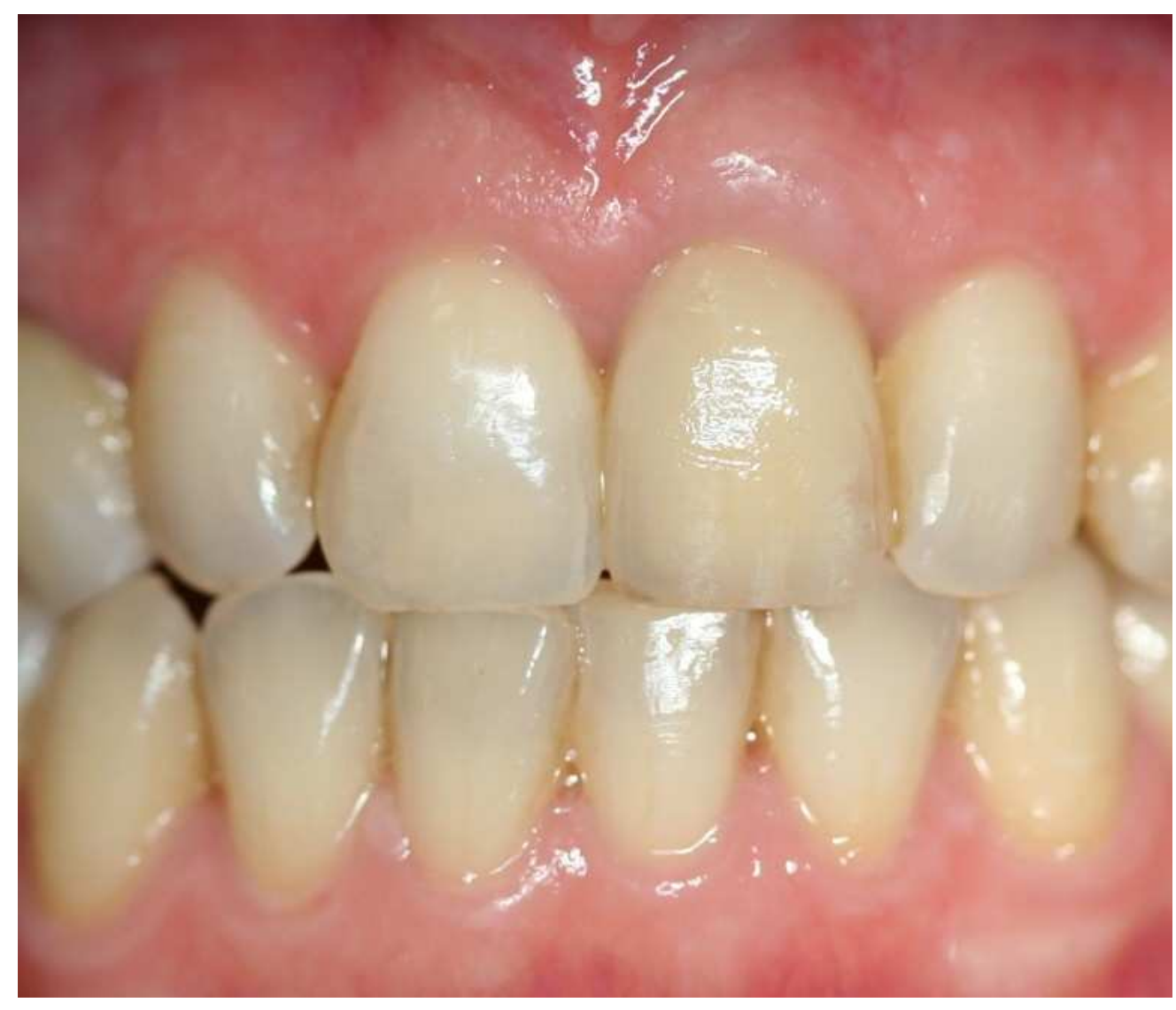

$271 \times 231 \mathrm{~mm}(72 \times 72 \mathrm{DPI})$ 


\section{$\underline{\text { LEGEND FOR FIGURE } 1}$}

Fig. 1. One-year and 3-year result of a single-implant case. 
Fig. 2. Cumulative percent of the Pink Esthetic Score.

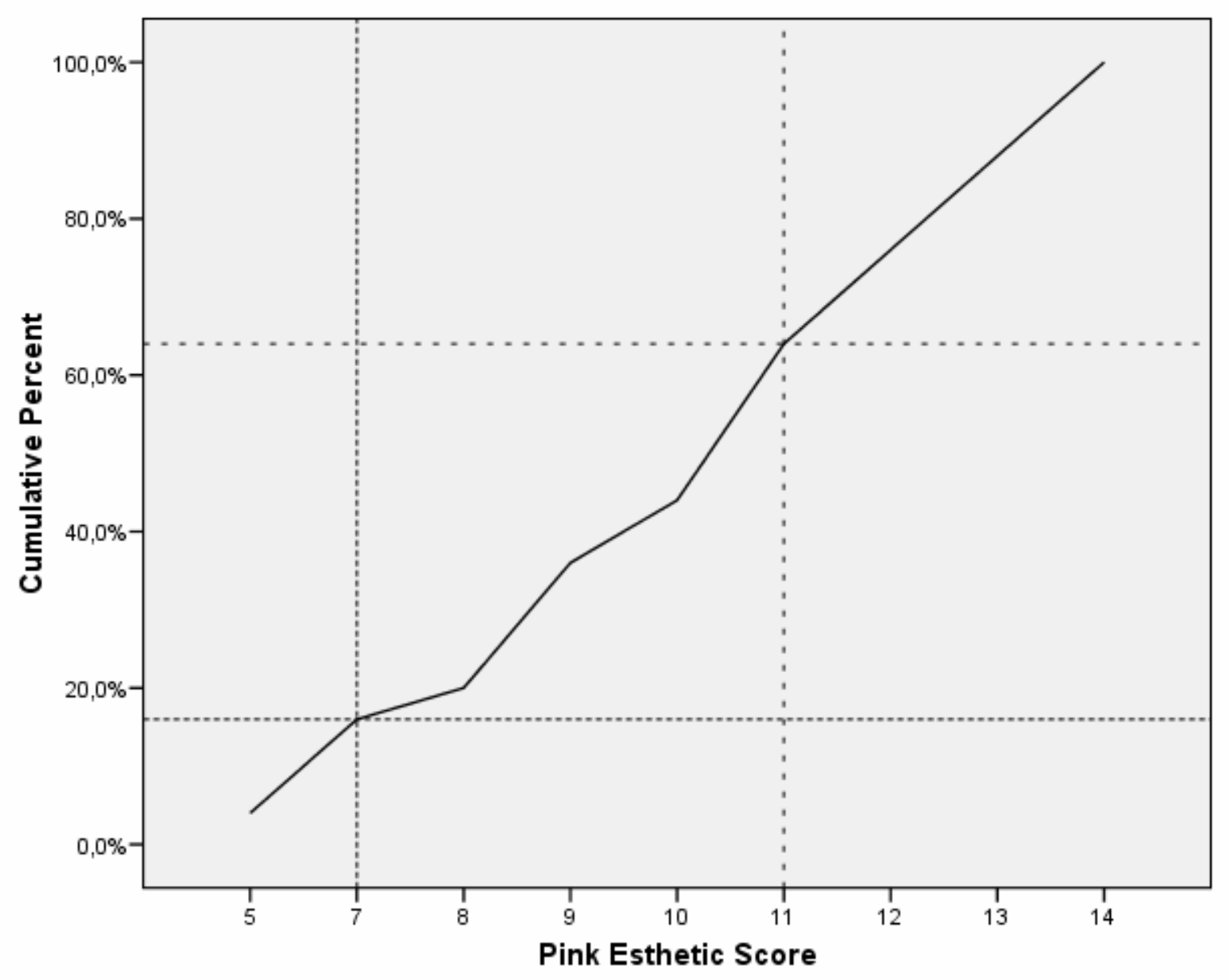


Fig. 3. Cumulative percent of the White Esthetic Score.

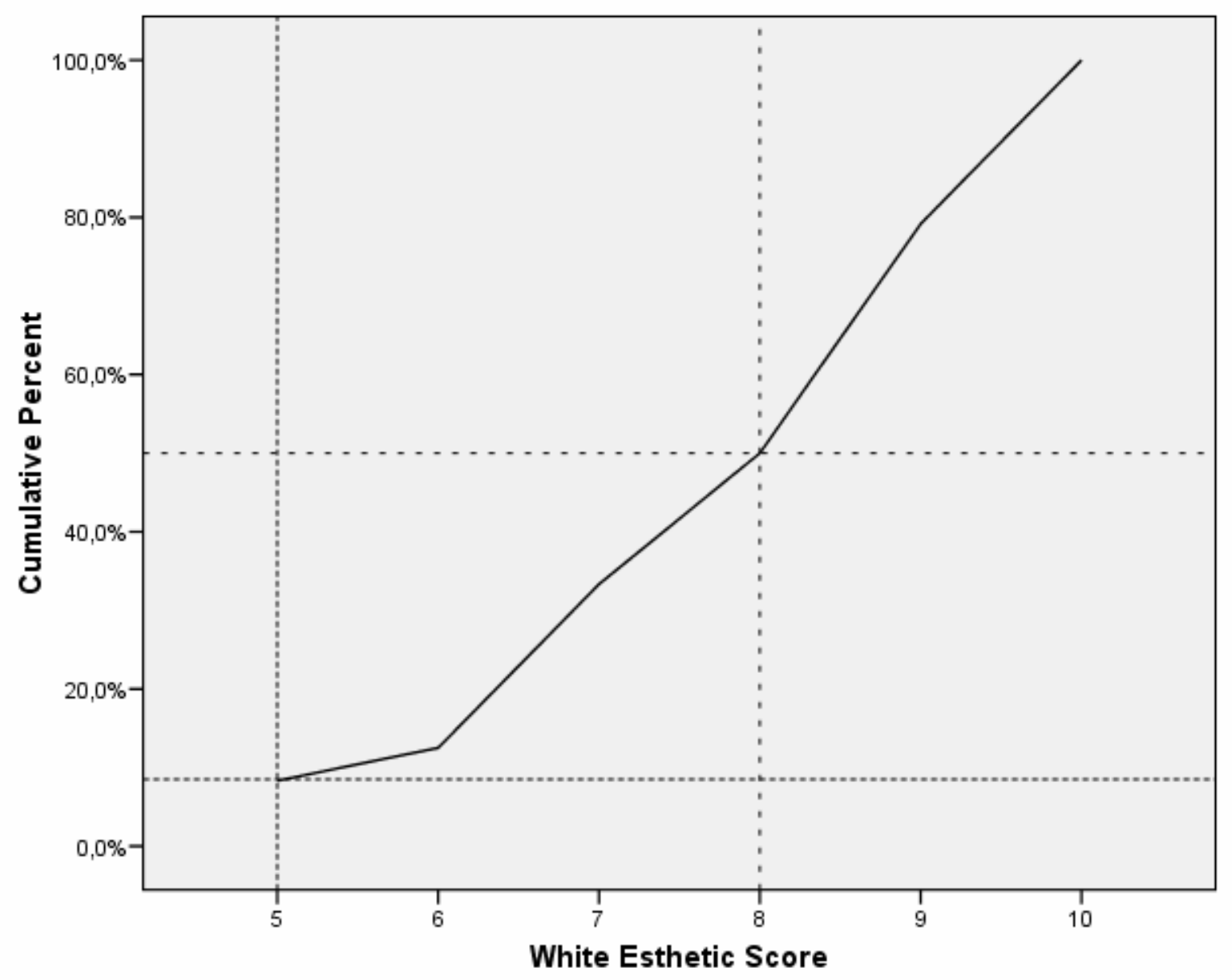

